\title{
Khalifa University Students' Attitudes Towards Mathematics in the Light of Variables Such as Gender, Nationality, Mathematics Scores and the Course they are Attending
}

\author{
Yousef Abosalem \\ Department of Mathematics and Science/ Preparatory Program, Khalifa University, Abu Dhabi, United Arab Emirates
}

Email address:

Yousef.abosalem@kustar.ac.ae

To cite this article:

Yousef Abosalem. Khalifa University Students' Attitudes Towards Mathematics in the Light of Variables Such as Gender, Nationality, Mathematics Scores and the Course they are Attending. Education Journal. Vol. 4, No. 3, 2015, pp. 123-131. doi: 10.11648/j.edu.20150403.15

\begin{abstract}
This study was aimed at identifying the attitudes of the students of Khalifa University towards mathematics . The sample of this study consisted of 88(out of 216) students distributed evenly according to gender. $56.9 \%$ of the sample were Emiraties and $53.1 \%$ were expatriates. The Attitude Towards Mathematics Inventory (ATMI) was implemented in collecting the data. The results of this study indicated that there were slight statistically significant differences between students' attitudes towards mathematics and mathematics achievement scores, age, the course they are attending, students' high school type, gender and their academic level. Additionally, the results indicated that there were statistically significant differences between self-confidence, enjoyment and value with and students' nationalities. Expatriates students showed higher positive attitudes towards mathematics than the Emirati students. Also, the results showed that there was a slight statistical relationship between enjoyment and students' academic level. Finally, this study revealed that $62.67 \%$ of the sample have self-confidence in dealing with mathematics, $84.4 \%$ felt that mathematics has a great value to them, and $75.49 \%$ showed enjoyment in dealing with mathematics.
\end{abstract}

Keywords: Attitudes, Mathematics, Gender, Nationality, Course Attending

\section{Introduction}

Researches on students' attitudes toward mathematics have acquired increasing attention. Many studies outlined that mathematics learning is influenced by several factors; such as motivation, curriculum, teacher and his way of teaching and educational teaching aids he used (Cote \& Levine, 2000; Singh et al., 2002; Olatunde, 2009; Howie, 2005; Singh, et al., 2002). Also, Hill (2004) indicated that integrating mathematics and science curriculum does improve students' attitude toward mathematics. Yet, regardless of the amount of effort spend in the improvement and development of mathematics learning process, efforts will have a slight impact on achievement unless there is a positive attitude towards mathematics. (Ma \& Kishor, 1997; Ma, \& Xu, 2004). However, many factors have influences on students' attitudes toward mathematics. Teachers, parents, and peers, as well as the school environment, all have influences on an individual's attitude. Wilkins and MA (2003) showed that teachers', peers', and parents' positive support will help in creating positive attitude and beliefs about mathematics and thus help restrain negative attitudes and beliefs. Whereas Ames (1992) considered student's home environment and access to instructional materials can all have an impact on his/her attitude and achievement.

\subsection{Purpose of the Study}

The general purpose of this study was to find out the attitudes of the students of Khalifa University towards mathematics. The study is focused on the relationship of their attitudes towards mathematics with other factors such as; gender, mathematics scores, high school type, nationality, academic level, age and the mathematics course they are attending.

\subsection{Research Questions}

This study aimed to answer the following questions:

1. What is the prelateship between students' attitudes towards mathematics and academic achievement?

2. What is the relationship between students' attitudes towards mathematics and gender? 
3. What is the relationship between students' attitudes towards mathematics and nationality?

4. What is the relationship between attitudes towards mathematics and academic level (foundation or freshmen year)?

5. What is the relationship between attitudes towards mathematics and age?

6. What is the relationship between attitudes towards mathematics and mathematics courses they are attending?

7. What is the relationship between attitudes towards mathematics and high school type?

\subsection{Definition of Terms}

The following definitions are provided for terms having special applications to this study.

1. Attitude - "refers to someone's basic liking or disliking of familiar target" (Hannula, 2002; p.25)

2. High School Type: The high school type refers to either private or government school.

3. Academic Level: The academic level refers to whether the student is in foundation or freshman year.

4. Nationality: The nationality refers to whether the student is an Emirati or an Expatriate.

\subsection{Literature Review}

Many studies have studied the students' attitudes towards mathematics and the impact of that on their achievement. Gottfried (1985) reported in his study that students who value and enjoy mathematics have a higher level of achievement. As well as, Ma and $\mathrm{Xu}$ (2004) outlined in their study that poor achievement has been linked to a decline in mathematics attitude. Therefore, achievement in mathematics caused a positive attitude. However, a positive attitude towards mathematics does not lead to a good achievement. Other factors might affect students' achievement in mathematics such as textbooks, and teacher quality (Howie, 2005). Yet, both Tapia and Marsh II (2004) argue that students who do well in mathematics showed positive attitudes, consequently they are likely to take more mathematics courses. So, attitude and achievement affect each other in a cyclical manner (Schiefele \& Csikszentmihalyi, 2004). Whereas, Ma and Kishor (1997) concluded that the relationship between attitudes towards mathematics and mathematics achievement is not a strong enough. Along with that, Phonguttha, et al. (2009) agreed with Ma and Kishor that mathematics achievement and attitude towards mathematics are not correlated. Furthermore, Casey et al. (1997) and Ma (1999) showed that the relationship between attitude and mathematics achievement exists only with respect to specific or particular mathematics content areas. Maple and Stage (1991) indicated that students' attitude towards mathematics could be used as a predictor of selecting a mathematics major but not for achievement. Whereas, Oakes (1990) argued that students with lower levels of achievement in mathematics confine students' career alternatives involving mathematical skills.

Other studies outlined that students' achievement in mathematics is influenced by a variety of factors other than students' attitudes towards mathematics, such as gender, teacher's experience, parents, socioeconomic status, ethnicity, cultural background, grade level and peers (Casey et al, 1997; Ho, et al., 2000; Ma \& Kishor, 1997; Ma, 1999, 1997; Carrier, 2008; Isiksal, 2008). Moreover, other researchers outlined that students' attitudes towards mathematics can be affected by teacher attitudes and beliefs (Uusimaki \& Nason, 2004; Beswick, 2006; Wilkins \& Brand, 2004; Swan, Bell, et al., 2000; Schoenfeld, 1985; Beswick, 2007). Along with that, teaching techniques were considered by many researchers as other factors that could affect students' attitudes toward mathematics (Anderson, 2005; Townsend et. al., 1998; Higgins, 1997; Pearce et. al., 1999; Mitchell, 1999; Kinney, 2001; Yusof \& Tall, 1998; Elliott et. al., 2001; Raymond \& Leinenbach, 2000; Whitin, 2007). Furthermore, Tymms (2001) stated that the most important factors affecting students' attitudes towards mathematics were the teacher and student academic level; while gender, age and language were weakly related with students' attitudes. Koller, et al. (2001) researched gender differences in mathematics achievement, which showed that male achievement is higher than that of female one especially in advanced mathematics courses. However, other researchers (Tapia \& Molavan (2007; Tapia \& Marsh II, 2004; Isiksal \& Cakiroglo, 2008) showed that gender had no impact on students' attitudes towards mathematics and male and female students had the same average mathematics score. Vaughan (2002) introduced another factor that has a direct impact on students' attitudes towards mathematics. He stated that using cooperative learning in our schools will increase the interaction between students and consequently produce positive attitudes towards mathematics and academic achievement.

\section{Methods}

This study was aimed at identifying the attitudes of the students of Khalifa University towards mathematics in the light of variables such as gender, nationality, mathematics scores and the course they are attending

\subsection{Data Collection Instrument}

In this study the Attitudes Towards Mathematics Inventory (ATMI) was used to collect the data about students' attitudes towards mathematics. ATMI consists of 40-items, 5-points Likert scale ranging from strongly disagree to strongly agree distributed by using exploratory factor analysis into four areas or domains related to attitudes towards mathematics including self-confidence (15 items), value(10 items), enjoyment( 10 items), and motivation( 5 items) as shown in table 1 . The instrument has a reliability coefficient alpha of 0.97 with standard error of measurement of 5.67 (Tapia, 1996). Also, the inventory demonstrates content and constructs validities. 
Table 1. The distribution of the ATMI scale according to the four domains.

\begin{tabular}{lll}
\hline Domain & Items & Total \\
\hline Self-confidence & $9,10,11,12,13,14,15,16,17,18,19,20,21,22,40$ & 15 \\
Value & $1,2,4,5,6,7,8,35,36,39$ & 10 \\
Enjoyment & $3,24,25,26,27,29,30,31,37,38$ & 10 \\
Motivation & $23,28,32,33,34$ & 5 \\
Total & & 40 \\
\hline
\end{tabular}

\subsection{Sample}

The sample of this study consisted of 88 out of 216 undergraduate students at Khalifa University randomly selected from all students enrolled in the pre-calculus, calculus-I, and calculus-II courses whose ages ranged from 18 to 22 years old and agreed to participate in this research. As shown in table 2, $44(50 \%)$ students of the sample were male and the same number was female. 58(66\%) students were Emiratis and $30(34 \%)$ students were expatriates.

Table 2. The sample distribution according to gender, age, and nationality.

\begin{tabular}{|c|c|c|c|c|c|c|c|}
\hline \multirow{2}{*}{ Gender } & \multirow{2}{*}{ Nationality } & \multicolumn{5}{|c|}{ Age(years) } & \multirow{2}{*}{ Total } \\
\hline & & 18 & 19 & 20 & 21 & 22 & \\
\hline \multirow{3}{*}{ Male } & UAE & 1 & 19 & 12 & 1 & 0 & 33 \\
\hline & Expatriates & 3 & 6 & 1 & 0 & 1 & 11 \\
\hline & Total & 4 & 25 & 13 & 1 & 1 & 44 \\
\hline \multirow{3}{*}{ Female } & UAE & 4 & 14 & 7 & 0 & & 25 \\
\hline & Expatriates & 2 & 11 & 4 & 2 & & 19 \\
\hline & Total & 6 & 25 & 11 & 2 & & 44 \\
\hline Total & & 10 & 50 & 24 & 4 & & 88 \\
\hline
\end{tabular}

Table 3 and figure 1 demonstrate the sample distribution according to the mathematics courses they are attending and the type of the school they obtained their high school diploma from. $67(76.1 \%)$ of them obtained their high school diploma from government school and 21 were from private ones. Whereas, 24(23.9\%) students are in Pre-calculus, 27(30.7\%) students are in Calculus I and 37(42.04\%) students are in Calculus II.
Table 3. The sample distribution according to high school type, and course they are attending.

\begin{tabular}{llllll}
\hline \multirow{2}{*}{ High School Type } & Course & & & \multirow{2}{*}{ Total } \\
\cline { 2 - 4 } & Pre-Calculus & Calculus-I & Calculus-II & \\
\hline Government & 19 & 18 & 30 & 67 \\
Private & 5 & 9 & 7 & 21 \\
Total & 24 & 27 & 37 & 88 \\
\hline
\end{tabular}

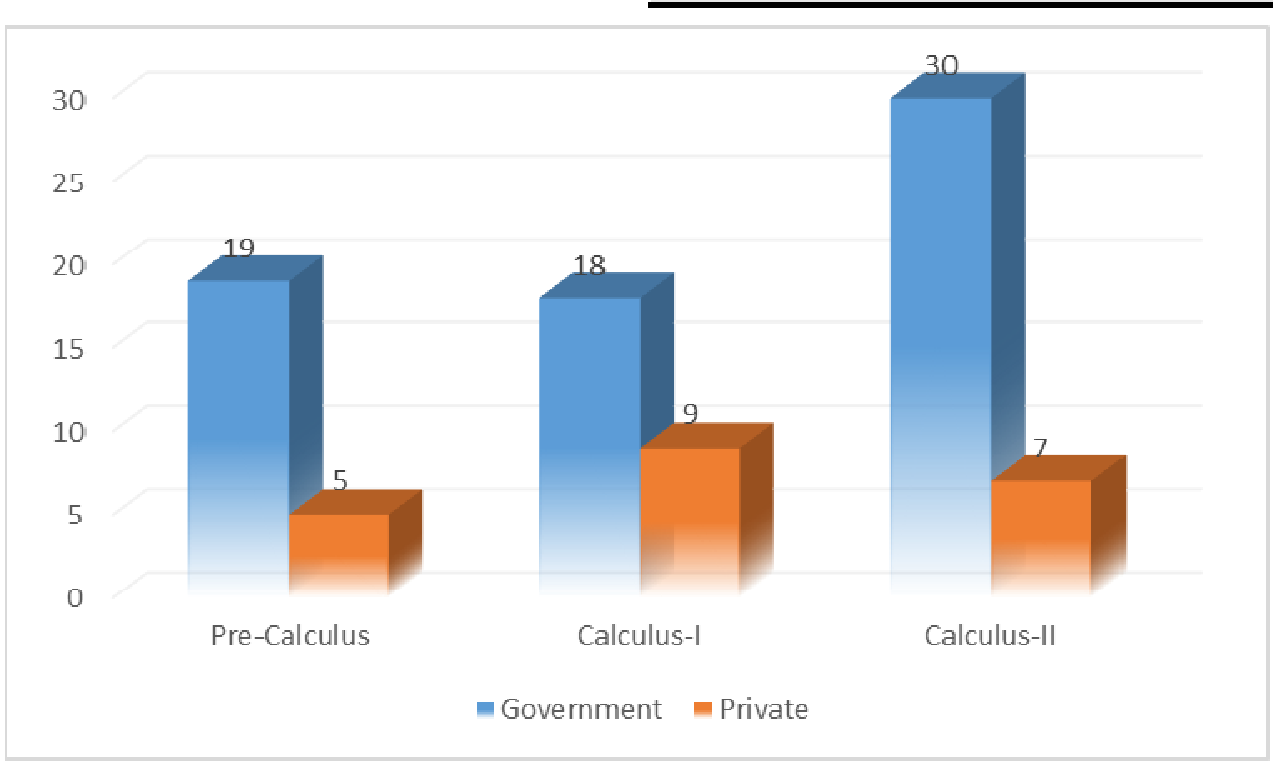

Figure 1. The sample distribution according to high school type and course they are attending.

\subsection{Results and Findings}

Research Question 1

What is the prelateship between students' attitude towards mathematics and academic achievement?

In order to the answer the first research question, and by assuming that the data is normally distributed according to
Kolomogrov and Shapirotests tests with $\mathrm{p}>0.05$, Pearson correlations were calculated. The results shown in table 4 outlined that there is a slight significant relationship between students' attitudes towards mathematics and mathematics achievement scores. However, this relation can explain 9.24\% of the variance, $90.76 \%$ unjustified or unexplained. 
Table 4. Pearson correlations between students' attitudes and academic achievement.

\begin{tabular}{llll}
\hline & & Attitude & Math Grade \\
\hline \multirow{4}{*}{ Attitude } & Pearson Correlation & 1 & $0.304^{*}$ \\
& Sig. (2-tailed) & & 0.017 \\
& $\mathrm{~N}$ & 76 & 61 \\
& Pearson Correlation & $.304^{*}$ & 1 \\
Math Grade & Sig. (2-tailed) & 0.017 & \\
& $\mathrm{~N}$ & 61 & 69 \\
\hline
\end{tabular}

*. Correlation is significant at the 0.05 level (2-tailed).

\section{Research Question 2}

What is the relationship between students' attitude towards mathematics and gender?

In order to find out if there is statistically significant differences between students' attitudes towards mathematics and gender. By assuming the homogeneity of the two variances according to Levene's test with $p>0.05$ as shown in table 5, and according to Kolmogorov-Smirnov and Shapiro-Wilk normality tests, we can assume that the data achieved the normality condition with $p>0.05$ as shown in table 6 . As shown in table 7 the means and standard deviations for the two groups are: 140.67, 140.70, 9.78, and 9.16 respectively. Four separate analyses of variances (ANOVA) were conducted as shown in table 8 . The results indicated that no statistically significant differences between the four domains and gender with $\mathrm{p}>0.05$.

Table 5. The levene's test of variances homogeneity.

\begin{tabular}{|c|c|c|c|c|c|c|}
\hline \multicolumn{7}{|c|}{ Levene's Test for Equality of Variances } \\
\hline \multirow[b]{2}{*}{ Attitude } & \multirow{2}{*}{\multicolumn{3}{|c|}{ Equal variances assumed }} & $\mathrm{F}$ & \multicolumn{2}{|l|}{ Sig. } \\
\hline & & & & 0.032 & 0.859 & \\
\hline \multicolumn{7}{|c|}{ Table 6. The normality test } \\
\hline \multicolumn{7}{|c|}{ Kolmogorov-Smirnov Shapiro-Wilk } \\
\hline \multirow{2}{*}{ Attitude } & Statistic & df & Sig. & Statistic & df & Sig. \\
\hline & 0.086 & 76 & $.200 *$ & 0.971 & 76 & 0.076 \\
\hline
\end{tabular}

Table 7. The descriptive statistics according to the gender.

\begin{tabular}{llllll}
\hline \multirow{2}{*}{ Attitude } & Gender & N & Mean & $\begin{array}{l}\text { Std. } \\
\text { Deviation }\end{array}$ & $\begin{array}{l}\text { Std. Error } \\
\text { Mean }\end{array}$ \\
\cline { 2 - 6 } & Male & 39 & 140.67 & 9.78 & 1.56563 \\
& Female & 37 & 140.7 & 9.16 & 1.50667 \\
\hline
\end{tabular}

Table 8. The four analysis of variances (ANOVA) according to the gender.

\begin{tabular}{|c|c|c|c|c|c|c|}
\hline Domain & & Sum of Squares & df & Mean Square & $\mathbf{F}$ & Sig. \\
\hline \multirow{3}{*}{ Self_Confidence } & Between Groups & 20.555 & 1 & 20.555 & \multirow{3}{*}{.867} & \multirow{3}{*}{.355} \\
\hline & Within Groups & 1848.195 & 78 & 23.695 & & \\
\hline & Total & 1868.750 & 79 & & & \\
\hline \multirow[b]{2}{*}{ Value } & Between Groups & .705 & 1 & .705 & \multirow{2}{*}{.030} & \multirow[b]{2}{*}{.862} \\
\hline & Within Groups & 1933.601 & 83 & 23.296 & & \\
\hline \multirow{3}{*}{ Enjoyment } & Between Groups & 2.012 & 1 & 2.012 & \multirow{3}{*}{.076} & \multirow{3}{*}{.784} \\
\hline & Within Groups & 2174.690 & 82 & 26.521 & & \\
\hline & Total & 2176.702 & 83 & & & \\
\hline \multirow{3}{*}{ Motivation } & Between Groups & .440 & 1 & .440 & \multirow{3}{*}{.079} & \multirow{3}{*}{.779} \\
\hline & Within Groups & 460.383 & 83 & 5.547 & & \\
\hline & Total & 460.824 & 84 & & & \\
\hline
\end{tabular}

\section{Research Question 3}

What is the relationship between students' attitudes towards mathematics and nationality?

In order to find out if there is a statistically significant difference between students' attitudes toward mathematics and nationalities, the homogeneity of the two variances was assumed according to Levene's test with $p>0.05$ as shown in table 9 and descriptive statistics shown in table-10. As shown previously in table-6, it can be assumed that the data is normally distributed. Four separate analyses of variances (ANOVA) were conducted as shown in table 11. The results indicated that there is a statistically significant difference between self-confidence $\mathrm{F}(1,78)=9.699$ and $p=0.03$, enjoyment $\mathrm{F}(1,82)=15.285$ and $p=0.001$, and value $\mathrm{F}(1,83)$ $=6.419$ and $\mathrm{p}=0.013$, and students' nationalities at $\alpha=0.05$.
However, the results showed that there is no statistically significant difference between motivation $F(1,83)=1.148$ and $p=0.228$, and nationality at $\alpha=0.05$. No Post Hoc comparisons were conducted because the number of values in each domain is less than three values. However, according to the descriptive statistics mentioned in table 10, we can conclude that the other nationalities with a mean value of 142.79 have higher positive attitudes towards mathematics than UAE students with a mean of 139.46.

Table 9. The levene's test of variances homogeneity.

\begin{tabular}{llll}
\hline \multicolumn{4}{l}{ Levene's Test for Equality of Variances } \\
\hline \multirow{2}{*}{ Attitude } & $\begin{array}{l}\text { Equal variances } \\
\text { assumed }\end{array}$ & $\mathrm{F}$ & Sig. \\
\hline
\end{tabular}


Table 10. The descriptive statistics according to the nationalities.

\begin{tabular}{lllllll}
\hline Nationality & & N & Min. & Max. & Mean & Std. Deviation \\
\hline \multirow{2}{*}{ UAE } & Attitude & 48 & 108 & 160 & 139.4583 & 9.25745 \\
& Valid N (leastwise) & 48 & & 158 & 142.7857 & 9.49213 \\
\multirow{2}{*}{ Others } & Attitude & 28 & 117 & & & \\
\hline
\end{tabular}

Table 11. The four analyses of variances (ANOVA) according to the nationalities.

\begin{tabular}{|c|c|c|c|c|c|c|}
\hline Domain & & Sum of Squares & df & Mean Square & $\mathbf{F}$ & Sig. \\
\hline \multirow{3}{*}{ Self_Confidence } & Between Groups & 206.67 & 1 & 206.67 & 9.699 & \\
\hline & Within Groups & 1662.08 & 78 & 21.309 & & 0.003 \\
\hline & Total & 1868.75 & 79 & & & \\
\hline \multirow{3}{*}{ Value } & Between Groups & 138.85 & 1 & 138.85 & 6.419 & \\
\hline & Within Groups & 1795.456 & 83 & 21.632 & & 0.013 \\
\hline & Total & 1934.306 & 84 & & & \\
\hline \multirow{3}{*}{ Enjoyment } & Between Groups & 342.002 & 1 & 342.002 & 15.285 & \\
\hline & Within Groups & 1834.7 & 82 & 22.374 & & 0 \\
\hline & Total & 2176.702 & 83 & & & \\
\hline \multirow{3}{*}{ Motivation } & Between Groups & 8.063 & 1 & 8.063 & 1.478 & \\
\hline & Within Groups & 452.76 & 83 & 5.455 & & 0.228 \\
\hline & Total & 460.824 & 84 & & & \\
\hline
\end{tabular}

\section{Research Question 4}

What is the relationship between attitudes towards mathematics and academic level (foundation or freshmen year)?

In order to find out if there is statistically significant differences between students' attitudes towards mathematics and their academic level. The homogeneity of the two variances and the data that was normally distributed were assumed according to Levene's test with $p>0.05$ as shown in table 12. Based on the descriptive statistics shown in table 13 and according to Kolmogorov-Smirnov and Shapiro-Wilk normality tests, four separate analyses of variances (ANOVA) were conducted as shown in table 14. The results indicated that there is no statistically significant difference between students' attitudes towards mathematics and students' academic year at $\alpha=0.05$. However, the analysis showed that there is a slight statistically significant difference between enjoyment and student's academic level $\mathrm{F}(1,82)=4.198$ with $p=0.044$ favor to freshman students ( $\bar{x}=140.88$ ).

Table 12. The levene's test of variances homogeneity.

\begin{tabular}{llll}
\hline \multicolumn{2}{l}{ Levene's Test for Equality of Variances } \\
\hline & F & Sig. \\
Attitude & Equal variances assumed & 1.038 & 0.312 \\
\hline
\end{tabular}

Table 13. The descriptive statistics according to attitude and academic level.

\begin{tabular}{llllll}
\hline & Academic Level & N & Mean & Std. Deviation & Std. Error Mean \\
\hline Attitude & Foundation & 18 & 140.0556 & 7.97402 & 1.87949 \\
& Freshman & 58 & 140.8793 & 9.88189 & 1.29756 \\
\hline
\end{tabular}

Table 14. The four analysis of variances(ANOVA) according to the academic level and attitude.

\begin{tabular}{|c|c|c|c|c|c|c|}
\hline Domain & & Sum of Squares & df & Mean Square & $\mathbf{F}$ & Sig. \\
\hline \multirow{3}{*}{ Self_Confidence } & Between Groups & 88.817 & 1 & 88.817 & \multirow{3}{*}{3.892} & \multirow{3}{*}{0.052} \\
\hline & Within Groups & 1779.933 & 78 & 22.82 & & \\
\hline & Total & 1868.75 & 79 & & & \\
\hline \multirow{3}{*}{ Value } & Between Groups & 9.287 & 1 & 9.287 & \multirow{3}{*}{0.4} & \multirow{3}{*}{0.529} \\
\hline & Within Groups & 1925.019 & 83 & 23.193 & & \\
\hline & Total & 1934.306 & 84 & & & \\
\hline \multirow{3}{*}{ Enjoyment } & Between Groups & 106.002 & 1 & 106.002 & \multirow{3}{*}{4.198} & \multirow{3}{*}{0.044} \\
\hline & Within Groups & 2070.7 & 82 & 25.252 & & \\
\hline & Total & 2176.702 & 83 & & & \\
\hline \multirow[t]{3}{*}{ Motivation } & Between Groups & 1.32 & 1 & 1.32 & \multirow{3}{*}{0.238} & \multirow{3}{*}{0.627} \\
\hline & Within Groups & 459.504 & 83 & 5.536 & & \\
\hline & Total & 460.824 & 84 & & & \\
\hline
\end{tabular}




\section{Research Question 5}

What is the relationship between students' attitudes towards mathematics and age?

In order to answer the fifth research question, and by assuming that the data is normally distributed according to Kolomogrov and Shapirotests with $\mathrm{p}>0.05$, Pearson correlations were calculated. The results shown in table 15 outlined that there is no meaningful relationship between students' attitudes towards mathematics and age at $\alpha=0.05$. However, only this relationship can explain $4.7 \%$ of the variance, $95.3 \%$ unjustified or unexplained.

Table 15. The correlations between students' attitude towards mathematics and age.

\begin{tabular}{llll}
\hline & & Attitude & Age \\
\hline \multirow{4}{*}{ Attitude } & Pearson Correlation & 1 & -0.217 \\
& Sig. (2-tailed) & & 0.06 \\
& N & 76 & 76 \\
\multirow{4}{*}{ Age } & Pearson Correlation & -0.217 & 1 \\
& Sig. (2-tailed) & 0.06 & \\
& N & 76 & 88 \\
\hline
\end{tabular}

\section{Research Question 6}

What is the relationship between attitudes towards mathematics and mathematics course they are attending?

In order to find out if there is a statistically significant difference between students' attitudes towards mathematics and the course they are attending. The homogeneity of the variances according to Levene's test with $p>0.05$ shown in table 16, the data is normally distributed according to Kolomogrov and Shapiro tests with $p>0.05$ were assumed. Four separate analyses of variances (ANOVA) were conducted as shown in table 18 . The results indicated that there is no statistically significant difference between students' attitudes towards mathematics and the course they are attending at $\alpha=0.05$.

Table 16. The levene's test of variances homogeneity.

\begin{tabular}{|c|c|c|c|}
\hline \multicolumn{4}{|c|}{ Levene's Test for Equality of Variances } \\
\hline Attitude & Equal variances assumed & $\begin{array}{l}\mathrm{F} \\
0.001\end{array}$ & $\begin{array}{l}\text { Sig. } \\
0.979\end{array}$ \\
\hline
\end{tabular}

Table 17. The four analyses of variances (ANOVA) according to the math. courses they are attending.

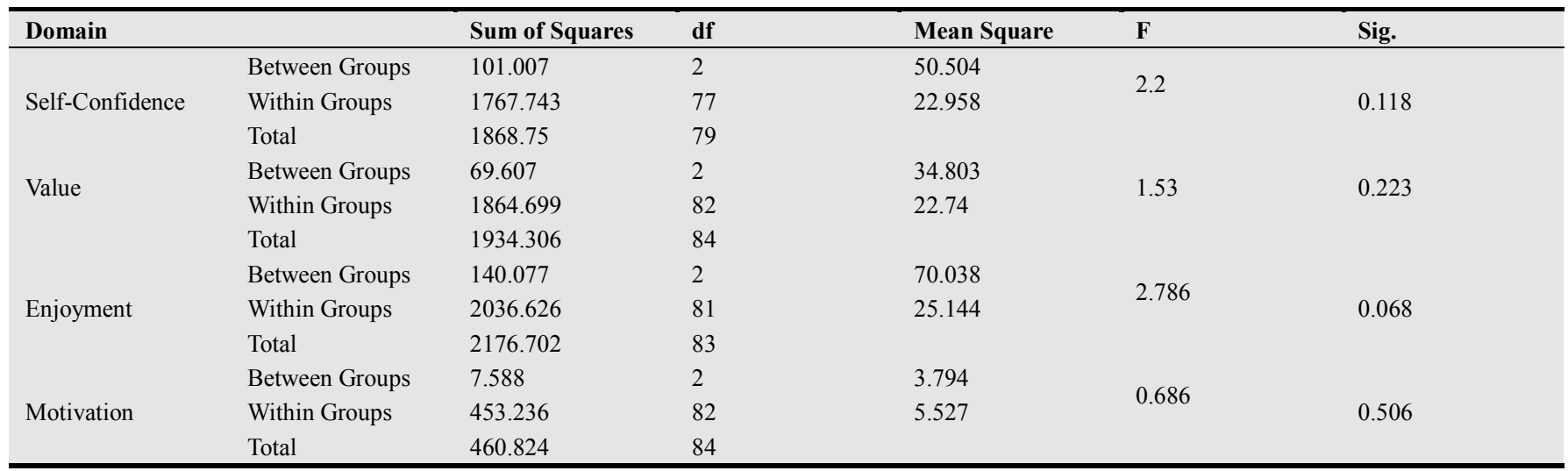

\section{Research Question 7}

What is the relationship between attitude towards mathematics and high school type?

In order to find out if there is a statistically significant difference between students' attitudes towards mathematics and high school type. By assuming that the homogeneity of the two variances according to Levene's test as shown in table 18 , and the data is normally distributed according to Kolomogrov and Shapiro tests with $p>0.05$. Four separate analyses of variances (ANOVA) were conducted as shown in table 19 .The results indicated that there is no statistically significant difference between students' attitudes and students' high school type.

Table 18. The levene's test of variances homogeneity.

\begin{tabular}{llll}
\hline \multicolumn{2}{l}{ Levene's Test for Equality of Variances } & & \\
& & F & Sig. \\
Attitude & Equal variances assumed & 0.001 & 0.979 \\
\hline
\end{tabular}

Table 19. The four analyses of variances (ANOVA) according to the high school type.

\begin{tabular}{|c|c|c|c|c|c|c|}
\hline Domain & & Sum of Squares & df & Mean Square & $\mathbf{F}$ & Sig. \\
\hline \multirow{3}{*}{ Self_Confidence } & Between Groups & 28.017 & 1 & 28.017 & & \\
\hline & Within Groups & 1840.733 & 78 & 23.599 & 1.187 & .279 \\
\hline & Total & 1868.750 & 79 & & & \\
\hline \multirow{3}{*}{ Value } & Between Groups & .090 & 1 & .090 & & \\
\hline & Within Groups & 1934.215 & 83 & 23.304 & .004 & .950 \\
\hline & Total & 1934.306 & 84 & & & \\
\hline \multirow{3}{*}{ Enjoyment } & Between Groups & 32.861 & 1 & 32.861 & & \\
\hline & Within Groups & 2143.841 & 82 & 26.144 & 1.257 & .266 \\
\hline & Total & 2176.702 & 83 & & & \\
\hline Motivation & Between Groups & 1.239 & 1 & 1.239 & .224 & .637 \\
\hline
\end{tabular}




\section{Data Analysis of the Four Domains}

\subsection{Self-Confidence Domain}

Table 20 showed that $62.67 \%$ of the sample revealed that
Khalifa University students felt self-confidence in their ability to do mathematics, whereas, $13.67 \%$ of them showed low self-confidence in their ability to do mathematics.

Table 20. The percentages and frequencies of students' responses on the Self-Confidence domain.

\begin{tabular}{|c|c|c|c|c|c|}
\hline Item & Strongly Disagree & Disagree & Neutral & Agree & Strongly Agree \\
\hline Item $9 *$ & 11 & 15 & 20 & 20 & 16 \\
\hline Item $10^{*}$ & 3 & 7 & 17 & 33 & 28 \\
\hline Item $11 *$ & 3 & 6 & 19 & 40 & 20 \\
\hline Item $12 *$ & 3 & 5 & 17 & 38 & 25 \\
\hline Item $13 *$ & 3 & 10 & 19 & 31 & 22 \\
\hline Item $14 *$ & 1 & 10 & 12 & 37 & 27 \\
\hline Item $15^{*}$ & 1 & 15 & 13 & 35 & 23 \\
\hline Item 16 & 1 & 14 & 18 & 32 & 21 \\
\hline Item 17 & 4 & 6 & 26 & 31 & 19 \\
\hline Item 18 & 2 & 13 & 31 & 33 & 8 \\
\hline Item 19 & 2 & 6 & 20 & 39 & 20 \\
\hline Item $20^{*}$ & 6 & 6 & 22 & 38 & 15 \\
\hline Item $21 *$ & 2 & 13 & 23 & 33 & 17 \\
\hline Item 22 & 1 & 5 & 27 & 39 & 16 \\
\hline Item 40 & 0 & 4 & 24 & 39 & 21 \\
\hline Total & 43 & 135 & 308 & 518 & 298 \\
\hline Percent & $3.30 \%$ & $10.37 \%$ & $23.66 \%$ & $39.78 \%$ & $22.89 \%$ \\
\hline
\end{tabular}

\subsection{Value Domain}

Table 21 showed that $84.40 \%$ of the sample revealed that Khalifa University student felt that mathematics has a great value to them. Whereas, $4.29 \%$ of them indicated that mathematics has no value for them.

Table 21. The percentages and frequencies of students' responses on the Value domain.

\begin{tabular}{llllll}
\hline Item & $\begin{array}{l}\text { Strongly } \\
\text { Disagree }\end{array}$ & Disagree & Neutral & Agree & $\begin{array}{l}\text { Strongly } \\
\text { Agree }\end{array}$ \\
\hline Item 1 & 4 & 1 & 1 & 17 & 63 \\
Item 2 & 3 & 0 & 3 & 9 & 70 \\
Item 3 & 0 & 3 & 17 & 35 & 30 \\
Item 4 & 1 & 1 & 5 & 30 & 49 \\
Item 5 & 1 & 1 & 16 & 38 & 32 \\
Item 6 & 0 & 2 & 7 & 36 & 43 \\
Item 7 & 0 & 6 & 7 & 38 & 37 \\
Item 8 & 2 & 8 & 30 & 35 & 12 \\
Item 35 & 0 & 4 & 9 & 46 & 28 \\
Item 36 & 0 & 2 & 6 & 41 & 38 \\
Item 39 & 0 & 2 & 7 & 37 & 42 \\
Total & 11 & 30 & 108 & 362 & 444 \\
Percent & $1.15 \%$ & $3.14 \%$ & $11.31 \%$ & $37.91 \%$ & $46.49 \%$ \\
\hline
\end{tabular}

* Indicated Reversed Items

\subsection{Motivation Domain}

Table 22 showed that $67.13 \%$ of the sample revealed that Khalifa University students are highly motivated to learn mathematics, whereas, $10.35 \%$ of them lack motivation.

Table 22. The percentages and frequencies of students' responses on the Motivation domain.

\begin{tabular}{llllll}
\hline Item & $\begin{array}{l}\text { Strongly } \\
\text { Disagree }\end{array}$ & Disagree & Neutral & Agree & $\begin{array}{l}\text { Strongly } \\
\text { Agree }\end{array}$ \\
\hline Item 23 & 0 & 6 & 15 & 45 & 22 \\
Item $28^{*}$ & 3 & 7 & 7 & 38 & 33 \\
Item 32 & 3 & 12 & 28 & 30 & 14 \\
Item 33 & 1 & 7 & 24 & 37 & 18 \\
Item 34 & 0 & 6 & 24 & 36 & 19 \\
Total & 7 & 38 & 98 & 186 & 106 \\
Percent & $1.61 \%$ & $8.74 \%$ & $22.53 \%$ & $42.76 \%$ & $24.37 \%$ \\
\hline
\end{tabular}

* Indicated Reversed Items

\subsection{Enjoyment Domain}

Table 23 showed that $75.49 \%$ of the sample reveals that Khalifa University students showed enjoyment in doing mathematics. Whereas, $7.90 \%$ of them indicated that mathematics is not an interesting subject. 
Table 23. The percentages and frequencies of students' responses on the Enjoyment domain.

\begin{tabular}{llllll}
\hline Item & $\begin{array}{l}\text { Strongly } \\
\text { Disagree }\end{array}$ & Disagree & Neutral & Agree & $\begin{array}{l}\text { Strongly } \\
\text { Agree }\end{array}$ \\
\hline Item 3 & 0 & 3 & 17 & 35 & 30 \\
Item 24 & 3 & 5 & 10 & 38 & 32 \\
Item $25^{*}$ & 4 & 5 & 5 & 38 & 36 \\
Item 26 & 2 & 5 & 15 & 44 & 21 \\
Item 27 & 8 & 4 & 10 & 20 & 46 \\
Item 29 & 2 & 1 & 10 & 38 & 36 \\
Item 30 & 2 & 11 & 21 & 36 & 17 \\
Item 31 & 0 & 4 & 12 & 40 & 31 \\
Item 37 & 2 & 3 & 25 & 41 & 17 \\
Item 38 & 1 & 4 & 20 & 39 & 24 \\
Total & 24 & 45 & 145 & 369 & 290 \\
Percent & $2.75 \%$ & $5.15 \%$ & $16.61 \%$ & $42.27 \%$ & $33.22 \%$ \\
\hline
\end{tabular}

* Indicated Reversed Items

\section{Discussion and Conclusions}

A common understanding around the world that is students of different ages and of different studying levels are facing difficulties when they attempting to do mathematics. Many researches indicated that these difficulties might due to mathematics teachers, curricula, assessment methods or/and teaching strategies used in schools and universities.

Many researches studied the effect of students' attitudes towards mathematics (see e.g. Tapia, 1996, 2004; Tapia\& Molavan, 2007) on academic achievement. Some studies outlined that there is no impact of the students' attitudes towards mathematics on their academic achievement (see e.g. Ma and Kishor, 1997; Phonguttha, et al., 2009). Other studies showed that there is a relationship between attitudes towards mathematics and achievement (see e.g. Gottfried 1985; Ma and Xu, 2004; Popham, 2005; Koller, et al. (2001).

This study aimed at identifying the attitudes of Khalifa University students towards mathematics in the light of some variables such as gender, nationality, mathematics scores and the course they are attending. The results of this study showed that there were no statistically differences between students' attitudes towards mathematics according to gender, academic level, high school type and nationality. The results of this study agreed with other studies (see e.g. Casey et al, 2001; Ho, et al., 2000; Ma \& Kishor, 1997; Ma, 1999, 1997; Tapia \& Molavan, 2007; Tapia \&Marsh II ,2004) in that there is no statistical difference between students' attitudes towards mathematics and other factors such as : gender, ethnicity, mathematics scores. In addition, this study outlined that $62.67 \%$ of Khalifa University students felt self-confidence in their ability to do mathematics, $84.40 \%$ of them felt that mathematics has a great value to them, $67.13 \%$ of them are highly motivated to learn mathematics, and $75.49 \%$ of the sample reveals that KUSTAR students showed enjoyment in doing mathematics.

Many factors have influences on students' attitudes towards mathematics. Teachers, parents, teaching strategies, assessment methods, and peers, as well as the school environment all have influences on an individual's attitude.
Tymms (2001) stated that the most important factors affecting students' attitudes towards mathematics such as the teacher and student academic level. Therefore more studies have to be conducted in the future to clarify the relationship between teachers' and teaching characteristics on students' attitudes towards mathematics. As well as, to determine how teachers can modify or change their students' attitudes towards mathematics if that is possible, and what the effect of using collaborative learning in schools and universities on changing students' attitudes towards mathematics is. Personally, I think class size, teaching methods and assessment techniques used in our schools and universities might have an impact on the students' attitudes towards mathematics and consequently on their achievements.

Finally, students' attitudes towards mathematics changed overtime because it could be replaced by other activities. Students in the early stages of schooling are given the mathematical concepts slowly and repeatedly by using different teaching aids, resulting in positive attitudes and high achievement for the majority of students. As the mathematical subjects gets more abstract and more diverse, students' attitudes and achievement started to decline or decrease (Ma \& Kishor, 1997; Hannula, 2002; Sanchez et al., 2004). The decline in students' attitude towards mathematics could be justified by the huge number of alternatives available for today's students.

\section{References}

[1] J. Anderson, "The relationship between student perceptions of team dynamics and simulation game outcomes: an individual-level analysis." Journal of Education for Business. 2005, 81(2), 85-90.

[2] K. Beswick, "Teachers' beliefs that matter in secondary mathematics classrooms."

[3] Educational Studies in Mathematics, 2005, 65(1), 95-120.

[4] K. Beswick, "Changes in pre-service teachers' attitudes and beliefs: the net impact of two mathematics education units and intervening experiences." School Science and Mathematics, 2006, 106(1), 36-47.

[5] S. J. Carrier, "Gender differences in attitudes toward environmental science." School Science and Mathematics, 2007, 107(7), 271-278

[6] M.B. Casey, R.L. Nuttall, \& E. Pezaris, "Mediators of gender differences in mathematics college entrance test scores: A comparison of spatial skills with internalized beliefs and anxieties.” Developmental Psychology, 1997, 33(4), 669-680.

[7] J.E. Cote, \& C. G. Levine, "Attitude versus aptitude: Is intelligence or motivation more important for positive higher-educational outcomes?" Journal of Adolescent Research, 2002, 15(1), 58-80.

[8] B. Elliott, K. Oty, J. McArthur, \& B. Clark, "The effect of an interdisciplinary algebra/science course on students' problem solving skills, critical thinking skills and attitudes toward mathematics." International Journal of Mathematical Education in Science \& Technology, 2001, 32(6), 811-816. 
[9] A. E. Gottfried, "Academic intrinsic motivation in elementary and junior high school students." Journal of Educational Psychology, 1985, 77(6), 631-645.

[10] M. Hannula, "Attitude towards mathematics: Emotions, Expectations and values." Educational studies in Mathematics, 2002, 49(1), 25-46.

[11] K. Higgins, "The effect of year-long instruction in mathematical problem solving on middle-school students' attitudes, beliefs, and abilities." Journal of Experimental Education, 1997, 66(1), 5-29.

[12] D. Hill, "Student attitudes toward integrated mathematics." Academic Exchange Quarterly, 2004, 8(2), 77-81.

[13] H. Ho, et. al., "The affective and cognitive dimensions of math anxiety: A cross-national study." Journal for Research in Mathematics Education, 2000), 31(3), 362-379.

[14] S. J. Howie, "Contextual factors at the school and classroom level related to pupils' performance in mathematics in South Africa." Educational Research and Evaluation, 2005, 11(2), 123-140.

[15] M. Isikal, and E. Cakiroglu, "Gender differences regarding mathematics achievement: the case of Turkish middle school." School Science and Mathematics, 2008, 108(3), 113-120.

[16] D. Kinney, "A comparison of computer-mediated and lecture classes in developmental mathematics." Research and Teaching in Developmental Mathematics, 2001, 18(1), 32-40.

[17] O. Koller, J. Baumert, and K. Schnable, "Does interest matter? The relationship between academic interest and achievement in mathematics." Journal for Research in Mathematics Education, 2001, 32(5), 448-470.

[18] S. A. Maple, and F. K. Stage, "Influences on the choice of math/science major by gender and ethnicity." American Educational Research Journal, 1991, 28(1), 37-60.

[19] X. Ma, and N. Kishor, "Assessing the relationship between attitude toward mathematics and achievement in mathematics: A meta-analysis." Journal for Research in Mathematics Education, 1997, 28(1), 26-47.

[20] X. Ma, "Dropping out of advanced mathematics: The effects of parental involvement." Teachers College Record, 1999, 101(1), 60-81.

[21] X. Ma, and J. Xu, "Determining the causal ordering between attitude toward mathematics and achievement in mathematics." American Journal of Education, 2004, 110(3), 256-280.

[22] T. Mitchell, "Changing student attitudes toward mathematics." Primary Educator, 1999, 5(4), 2-9.

[23] J. Oakes, "Opportunities, achievement, and choice: Women and minority students in science and mathematics. "Review of Research in Education, 1990, 16, 153-222.

[24] Y. P. Olatunde, "Students attitude towards mathematics and academic achievement in some selected secondary schools in Southwest Nigeria." European Journal of Scientific Research, 2009, 36(3), 336-341.
[25] K. Pearce, M. Lungren, and A. Wince, "The effects of curriculum practices on first graders' attitudes, activity preference, and achievements in mathematics." Education, 1999, 119(1), 82-90.

[26] R. Phonguttha, S. Tayraukham, and P. Nuangchalerm, "Comparisons of Mathematics Achievement, Attitude towards Mathematics and Analytical Thinking between Using the Geometer's Sketchpad Program as Media and Conventional Learning Activities." Australian Journal of Basic and Applied Sciences, 2009, 3(3), 3036-3039.

[27] W. Popham, "Students' attitudes count." Educational Leadership, 2005, 62(5), 84-85.

[28] A. Raymond, and M. Leinenbach, "Collaborative action research on the learning and teaching of algebra: a story of one mathematics teacher's development." Educational Studies in Mathematics, 2000, 41(3), pp. 283-307.

[29] K. Sanchez, L. Zimmerman, and R. Ye, "Secondary students' attitudes toward mathematics." Academic Exchange Quarterly, 2004, Summer, 56-60.

[30] K. Singh, M. Granville, and S. Dika, "Mathematics and science achievement: Effects of motivation, interest, and academic engagement." The Journal of Educational Research, 2002, 95(6), 323-332.

[31] M. Swan, A. Bell, R. Phillips, and A. Shannon, "The purpose of mathematical activities and pupils' perceptions of them." Research in Education, 2000, 63, 199-223.

[32] M. Tapia, and G. Marsh II, "The relationship of math anxiety and gender. " Academic Exchange Quarterly, 2004, summer, 130-134.

[33] M. Tapia, "The Attitudes Toward Mathematics Instrument." ERIC Document Reproduction Service No. 1996, ED404165.

[34] M. Tapia, and C.C Molavan, "Attitudes toward mathematics of pre-calculus and calculus students." Focus on Learning Problems in Mathematics, 2007, 29(1), 48-59.

[35] M. Townsend, D. Moore, B. Tuck, and K Wilton, "Self-concept and anxiety in university students studying social science statistics within a cooperative learning structure." Educational Psychology, 1998, 18(1), 41-54.

[36] P. Tymms, "A test of the big fish in a little pond hypothesis: An investigation into the feelings of seven-year-old pupils in schools." School Effectiveness and School Improvement, 2001, 12(2), 161-181.

[37] W. Vaughan, "Effects of cooperative learning on achievement and attitude among students of color." The Journal of Educational Research, 2002, 95(6), 359-364.

[38] P. Whitin, "The mathematics survey: a tool for assessing attitudes and dispositions." Teaching Children Mathematics, 2007, 13(8), 426-432.

[39] J. Wilkins, and X. Ma, "Modeling changes in student attitude toward and beliefs about mathematics." The Journal of Educational Research, 2003, 97(1), 52-63.

[40] Y.M. Yusof, and D. Tall, "Changing attitudes to University mathematics through problem solving." Educational Studies in Mathematics, 1998, 37(1), 67-82. 